\title{
木質ダイアフラムの面内振動特性に関する研究（第 1 報） IN-PLANE DYNAMIC CHARACTERISTICS OF WOODEN DIAPHRAGMS (Part I)
}

\author{
鈴木秀三*, 藤野栄一**, 野口弘行*** \\ Shuzo SUZUKI, Eiichi FUJINO and Hiroyuki NOGUCHI
}

\begin{abstract}
In-plane dynamic characteristics of wooden diaphragms were investigated using a full-scale and a model diaphragms. The full-scale diaphragm was a $11.18 \mathrm{~m}$-long by $6.38 \mathrm{~m}$-wide Swedish-type floor and the model diaphragm was a $2.40 \mathrm{~m}$-Jong by $1.20 \mathrm{~m}$-wide. Two tests among impact-hammer, exciting and shaking-table dynamic tests were altematively performed for both diaphragms. The test data of both diaphragms showed that the natural frequency was proportional to the mode number and that the mode shapes were similar to sine-curves. Furthermore, the calculated natural frequencies based on the shearing vibration theory with the equivalent shear-stiffness obtained by the static loading test agreed with the natural frequencies due to the dynamic tests. It was suggested that the dynamic in-plane behavior of wooden diaphragms was consistent with the shearing vibration theory.
\end{abstract}

Keywords : wooden-diaphragm, dynamic-characteristics, vibration-tests, modal-analysis, static-tests 木質ダイアフラム，動的特性，振動実験，モード解析，静加力実験

\section{§1。序}

木質構造においては，枠組に構造用合板などの面内せ ん断剛性の高い面材を張った水平構面はダイアフラムと 称され，屋根・床等に使用されている。梖ダイアフラ ムの静的面内性状については，米国に拉いて既に多くの 研究がなされてきており ${ }^{1)}$, 最近では, 著者らによる有 開口床, 勾配屋根, 半冈筒形屋根など特殊な形状につい ての静的実験および解析的な研究 2)，3がなされている。

ところで, ダイアフラムに作用する面内力は, 地震力 や風圧力など基本的に動的な荷重によるものであり，建 築物全体の水平力に対する動的挙動を考える上で，ダイ アフラムの動的特性を明らかにしておくことは必要不可 欠なことであると考えられる。しかしながら，既往の研 劦のほとんど全てがダイアフラムの静的性状を対象とし たもので，ダイアフラムの面内振動特性に関する報告は ほとんどないのが現状である。

著者らは，木質ダイアフラムの面内振動特性を明らか にすることを目的として㬰験を行ってきたが4)、5)，そ
れについて知見を得たので、ここに報告するものである。 本報では, 辺長比䄪 $1 / 2$ の実大及び模型ダイアフラム の結果について述べる。

\section{§2. 試験体と試験種類}

2.1 実大ダイアフラム

\subsection{1 試験体}

試験体は，Fig.1に示すようなスウェーテン式構法を 用いた平面形状 $11,180 \mathrm{~mm} \times 6,380 \mathrm{~mm}$ の水平ダイアフラ ムである。床組は, 周囲を端根太と側根太とにより囲み, その内部に床根太を $600 \mathrm{~mm}$ 間隔に配置したものである が，端根太及び側根太に接して壁受け材が平に配置され ている所に特徽がある。面材は，四周に本実加工 (T\&G) が施された厚さ $22 \mathrm{~mm}$ のパーティクルボード $(600 \mathrm{~mm} \times$ $2,400 \mathrm{~mm})$ で, ダイアフラム外周に配置された壁受け材 と床根太に釘打ちされるが, 受け材は省略されており， 面材同士の接合は T\&G 部に釷打ちすることにより行っ ている。構成部材寸法及び面材の留付け方法については,

\footnotetext{
* 職業能力開発大学校建築工学科 教授・工博

***職業能力開発大学校研究課程 学生

**** 明治大学理工学部建築学科 助教授.工博
}

Prof., Dept. of Architectural Engineering, The Polytechnic Univ. of Japan, Dr. Eng.

Graduate Student, Dept. of Architectural Engineering, The Polytechnic Univ. of Japan.

Assoc. Prof., Dept. of Architecture, School of Science and Technology, Meiji Univ., Dr. Eng. 


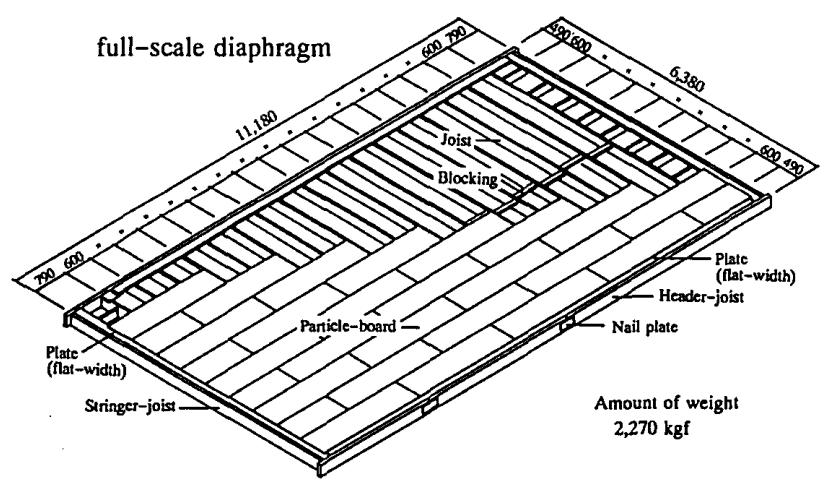

Fig.1 Schematic diagram of full-scale diaphragm

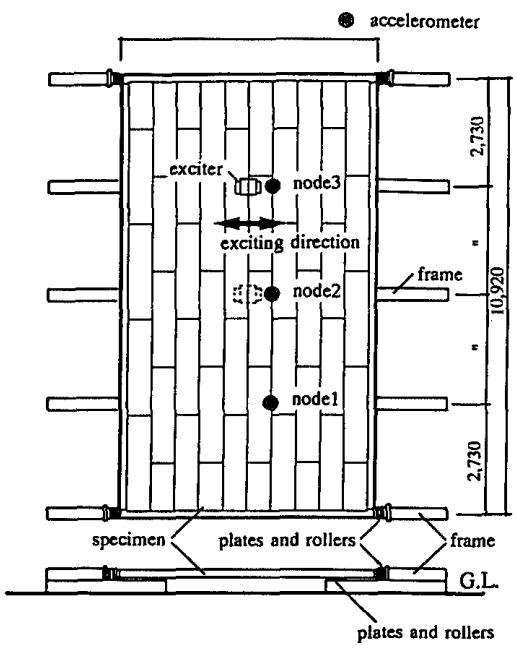

Fig.2 Schematic diagram of exciting test set-up for full-scale diaphragm

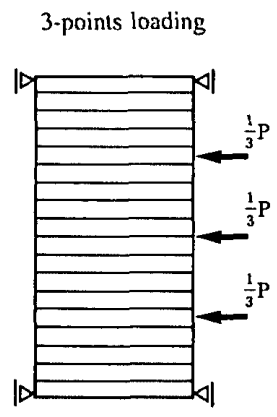

(a) full-scale

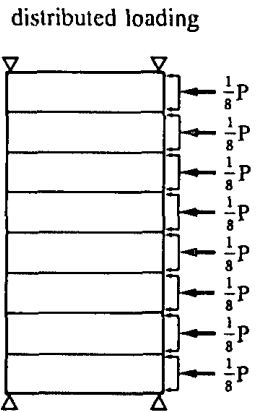

(b) model mid-span loading

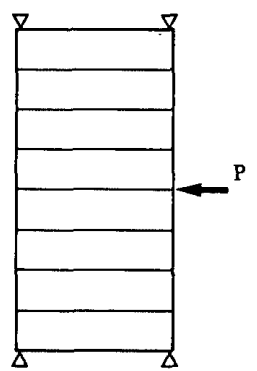

Fig.3 Loading conditions for static tests

Table 1 に示してあるので参照されたい。なお，製材， 面材及び組立用の釘は，全てスウェーテンで使用されて いるものである。

\subsection{2 試験種類}

実大ダイアフラムに対して行った実験は，2 種類の動 的試験と，面内㓮性を調へるための静的加力試験である。 動的及び静的試験いずれの場合にも，試験体をフレーム 上にローラーを介して置き，両端根太の両端部を短辺方 向にローラーで支持した状㮩で行った（Fig.2 参照）。
Table 1 Specification of members

\begin{tabular}{|c|c|c|}
\hline & Full-scale & Model \\
\hline Header-joist & $70 \times 220$ & $10 \times 60$ \\
\hline Stringer-joist & $70 \times 220$ & $10 \times 60$ \\
\hline Joist & $45 \times 220$ & $10 \times 60$ \\
\hline Blocking & $38 \times 89$ & $10 \times 60$ \\
\hline Sheathing & $\begin{array}{l}600 \times 2400(\mathrm{t}=22) \\
\text { particle-board }(T \& G)\end{array}$ & $\begin{array}{l}300 \times 300(t=3) \\
\text { plywood (3-ply) }\end{array}$ \\
\hline $\begin{array}{l}\text { Nailing-schedule } \\
\text { for sheathing }\end{array}$ & $\begin{array}{l}\text { Swedish nail } 28 \times 75 \\
\text { (D=2. 8. } \mathrm{L}=75 \text { ) } \\
\text { to plate (perimeter) } 075 \\
\text { to joist (edge) } 975 \\
\quad \text { (interior) } 9200 \\
\text { tongue and groove } 0200\end{array}$ & $\begin{array}{l}\text { nail } 17 \times 19 \\
(D=1.5, L=19) \\
\text { perimeter } 9100\end{array}$ \\
\hline
\end{tabular}

\section{A. 動的試験}

(1)インパクトハンマー加振による自由振動実験

Fig.2に示す 3 点 (○印： node1 node3) に压電型加 速度計 (感度 $1 \mathrm{~V} / \mathrm{g}$ )を取り付け, インパクトハンマーに より各 node 位置の端根太を, 床根太方向に水平加振す ることによって自由振動実験を行った。ダイアフラムの 固有振動数は，各 node の応答加速度に基づき，FFT 計 ラ价゙により計測した。なお，加振位置により励起され ないモードが生じることを避けるために， node1〜 node3について逐次加振を行った。

(2) 強制加振実験とモード解析

電磁式加振器（重量的 30kgf）を node2 または node3 に取り付け，床根太方向に水平加振を行った。入力には 加振器可動部の入力加速度を一定とするスウィープ波を 用い， $20 \sim 100 \mathrm{~Hz}$ の周波数範囲において，スウィープ 掃引時間を $4 \mathrm{~Hz} / \min$ として加振を行った。なお, 高次 の固有振動モードを明確に捉えるために, 加振器の取り 付け位置を変化させて（node2 または 3 ）実験を行った。 応答加速度の測定については，(1) と同様に node1 3 において行い，スパン中央部の変位は，渦電流型非接触 变位計（精度： $1 / 200 \mathrm{~mm}$ ) を用いて测定した。測定テ 一夕に基づいたモード解析に当たっては, 汎用モード解 析ソフト(LMS 社製)を用いた。

\section{B. 静的加力試験}

ダイアフラムの静的面内性状を調へることを目的とし て, 動的試験と同じ支持条件について, 動的試験終了後, 静的加力試験を行った。加力は Fig.3(a)に示すように, スパン 4 等分点に 3 点集中加力とし， 3 段階の正負絽り 返し加力の後，破壊に達するまで加力する方法によった。 なお，後述するか，本報の考察で必要としたデー夕は初 期の微小変形時のものであった。

\section{2 模型ダイアフラム}

\section{2 .1 試験体}

模型ダイアフラムは，ダイアフラムの基本的メカニス ムを有する実験用モデルであり，上述の実大ダイアフラ 


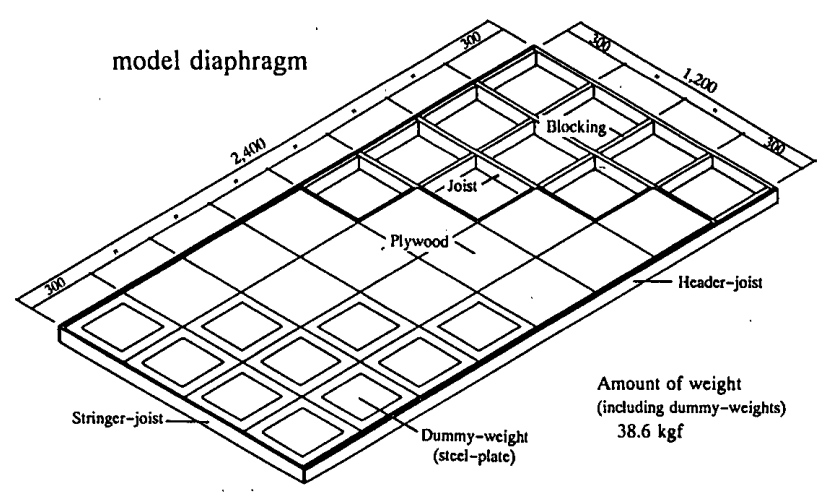

Fig.4 Schematic diagram of model diaphragm

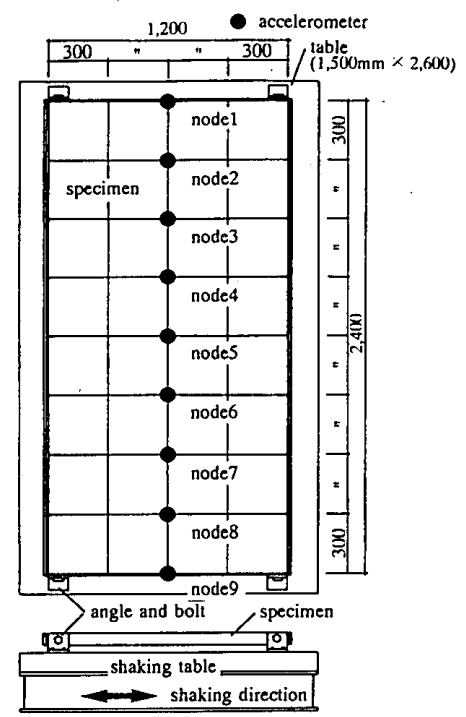

Fig.5 Schematic diagram of shaking-table test set-up for model diaphragm

ムの相似模型ではない。模型は Fig.4に示すような，平 面形状 $2,400 \mathrm{~mm} \times 1,200 \mathrm{~mm}$ の水平ダイアフラムで, 枠 組は端根太及び例根太に囲まれた内部に, 根太及び合板 受けを $300 \mathrm{~mm}$ 間隔に配したもので，面材は厚さ $3 \mathrm{~mm}$ の ラワン合板 (300 mm 角) である。枠組と面材の接合には 鉄丸釘 $(17 \times 19)$ を用いるが, 振動台の性能（加振周波 数範囲 DC 100Hz) の関係から, ダイアフラムの面内 剛性を低くする必要があったため，釷打ち間隔を $100 \mathrm{~mm}$ とし，さらに，厚さ $2 \mathrm{~mm}$ の鉄板 $(200 \mathrm{~mm}$ 角， 620gf/ 1 枚)をダミーウエイトとして, 全ての合板の中 央に両面接着テープで貼り付けている。なお，模型の構 成部材の寸法等は Table 1 に併記してあるので参照され たい。

\subsection{2 試験種類}

模型ダイアフラムに対して行った実験は，2 種類の動 的試験之, 面内剛性を調へるための静的加力試験である。 試験体の支持条件については，動的および静的試験いず れの場合にも，Fig.5に示したように，ダイアフラム四 隅の側根太端をボルトを用いて支持する状態で行われた。

\section{A. 動的試験}

(1)インパクトハンマー加振実験とモード解析

Fig.5に示すように，振動台上に支持された模型の各 根太中央部 (node1 〜 node9) に圧電型加速度計を取り付 け、各 node の端根太位置にインパクトハンマーにより 逐次水平加振を行った。測定デー夕は，入力をインパク トハンマーの加振力, 出力を各 node の応答加速度とし た周波数応答関数であり，得られた周波数応答関数に基 づて，多点参照モード解析を行った。

(2) 振動台を用いた周波数応答実験

木質ダイアフラムは非線形性状を有しているため, ダ イアフラムの変形が増加すると, 固有振動数の值が変化 することが予想される。本実験は，振動台を用いてダイ アフラムに対する入力加速度を变化させることにより， ダイアフラムの変形と振動特性の関係を明らかにするこ とを目的としたものである。加振には振動台の入力加速 度を一定とするスウィープ波（掃引時間： $5 \mathrm{~Hz} / \mathrm{sec}$ ）を 用い, 周波数範囲 $20 \sim 60 \mathrm{~Hz}$ で振動台の入力加速度を $0.02 \mathrm{~g} \sim 0.6 \mathrm{~g}$ の範囲で変化させ，周波数応答実験を行っ た。なお，入力加速度が $0.2 \sim 0.6 \mathrm{~g}$ の場合については， 各 node の応答加速度のほか，スパン中央部の応答変位 を渦電流型非接触変位計を用いて測定した。

B. 水平加力試験

動的試験の場合と同様な支持状態のダイアフラムに対 して, 静的加力試験を行った。加力方法は Fig.3 (b) に併 記してあるが，トーナメントを用いた 8 点等加力（以下 では「等分布加力」と呼ぶ）とスパン中央集中加力の 2 種類で、オイルジャッキを用いて面内せん断力を加える 方法により正負繰り返し加力を行い，スパン中央部の水 平方向変位を測定した。

\section{§ 3. 実験結果とその考察}

\section{1 実大ダイアフラムについての検討}

(1) 固有振動数

インパクトハンマー試験により得られた, 各モード次 数に対応する固有振動数の值は， 1 次で $28.8 \mathrm{~Hz} ， 2$ 次 で $59.0 \mathrm{~Hz} ， 3$ 次で $88.8 \mathrm{~Hz}$ であった。

Fig.6には, 強制加振実験により得られた加速度応答 曲線が示してある。強制加振実験より得られた各モード 次数に対応する固有振動数の值は，1 次で $28.5 \mathrm{~Hz} ， 2$ 次で $59.5 \mathrm{~Hz}$ または $63.5 \mathrm{~Hz}, 3$ 次で $84.0 \mathrm{~Hz}$ または $90.0 \mathrm{~Hz}$ であった。2 次及び 3 次の固有振動数については，モー ド形がほぼ同じ形をした接近した 2 つの固有振動数が存 在していた。この原因は明らかではないが，ダイアフラ 么の剛性 (正負の変形量) が振動方向により異なるため に生じたものと考えられる。

Fig.7には, 得られた固有振動数とモード次数の関係 が示してあるが, 同図より、インパクトハンマー試験お 


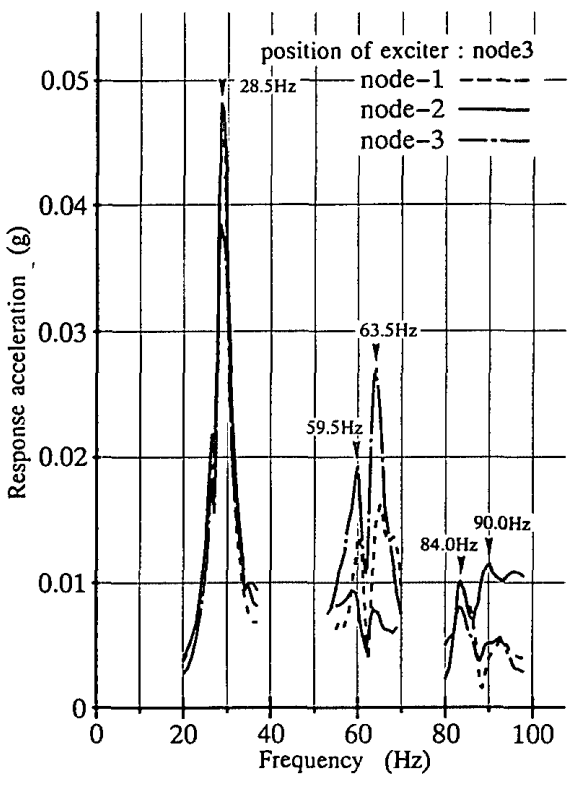

Fig.6 Frequency response curves obtained by exciting test for full-scale diaphragm

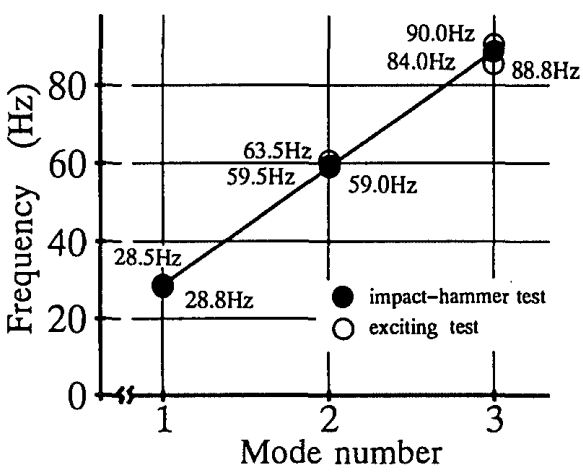

Fig.7 Relation between frequency and mode number obtained by tests for full-scale diaphragm

よび強制加振実験いずれの場合にも，固有振動数とモ一 ド次数の間には 1 次比例の関係が存在していることが看 取される。

連続体の振動理論によればをとネ(186), せん断振動の固有 振動数はモード次数に 1 次比例し, 曲げ振動の固有振動 数はモード次数の 2 乗に比例することになる [〈付録 1〉 参照]。このことから, 実大ダイアフラムの固有振動数 とモード次数との関係は，せん断振動理論に合致するも のであり, 本ダイアフラムの面内振動はせん断形の振動 であることを窥わせる。

(2) モード形

Fig.8には, 強制加振実験の結果を用たモード解析に より得られた, $1 \sim 3$ 次の固有振動数に対応するモード 形が示してある。同図より，モード形には加振位置の影 響が若干現れているものの，全体的に見れば，両端単純 支持梁の振動モード形（曲げ，せん断いずれの場合も同 じである sine 曲線と同じ傾向にあることがわかる。

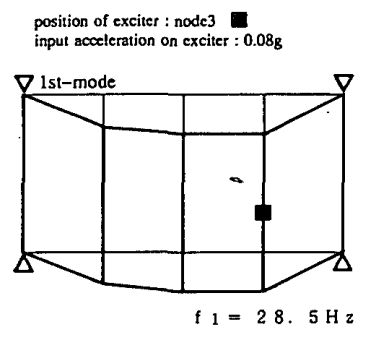

position of exciter : node2

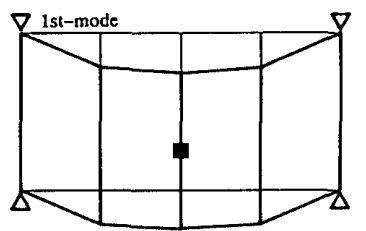

$f_{1}=28,5 \mathrm{~Hz}$
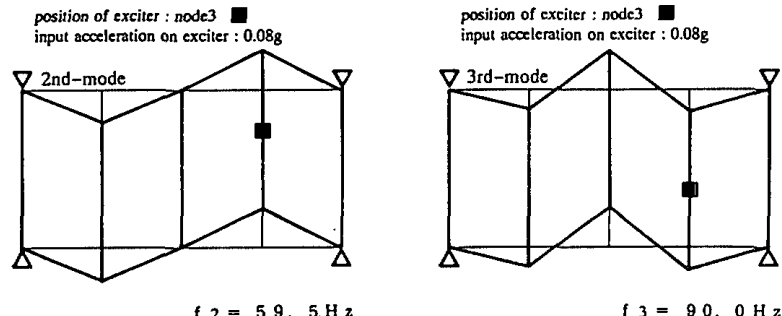

$f_{3}=90.0 \mathrm{~Hz}$

Fig.8 Mode shapes obtained by exciting test for full-scale diaphragm

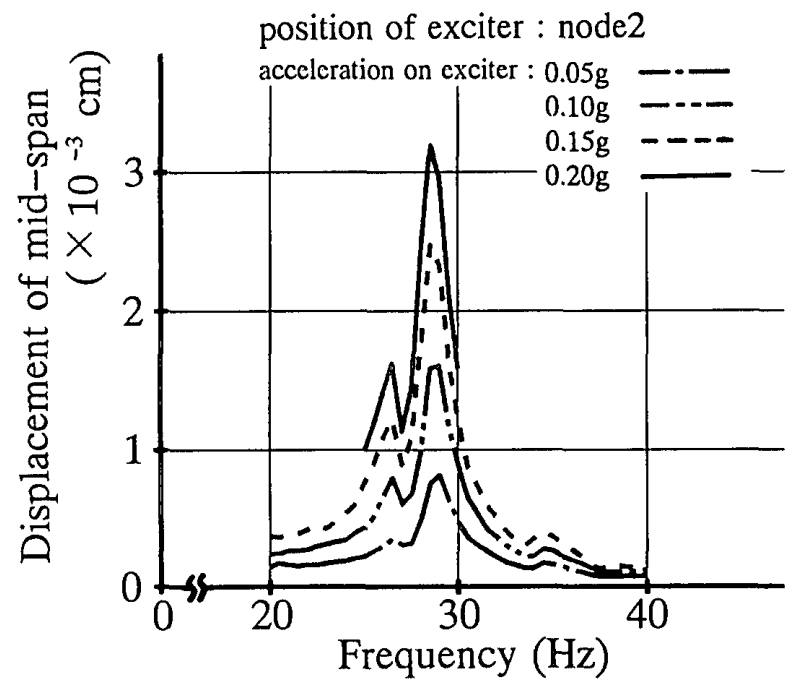

Fig.9 Variation of frequency response curves on mid-span displacement for full-scale diaphragm

(3) スパン中央部変位

Fig.9には, 強制加振実験のスパン中央部（node2） 加振時における，スパン中央部の水平変位応答曲線が示 してある。同図より, 加振器の入力加速度が $0.05 \sim$ $0.2 \mathrm{~g}$ の範囲において，最大応答変位は入力加速度に比例 して增大するものの， 1 次固有振動数は一定の值を示し ていることがわかる。このことは，微小振動においては， 本ダイアフラムの剛性が一定であることを示唆している。 また，実験で得られたスパン中央部最大応答変位は 3.2 $\times 10^{-3} \mathrm{~cm}$ （スパンに对する比は，約 $1 / 368,000$ ）であ り, 本報の加振器による強制加振実験においては, 実大 ダイアフラムに対する微小変形時の振動特性を調へてい ることがわかる。

(4) 堿衰定数

Fig.6の加速度応答曲線に基づき， $1 / \sqrt{2}$ 法を用いて 


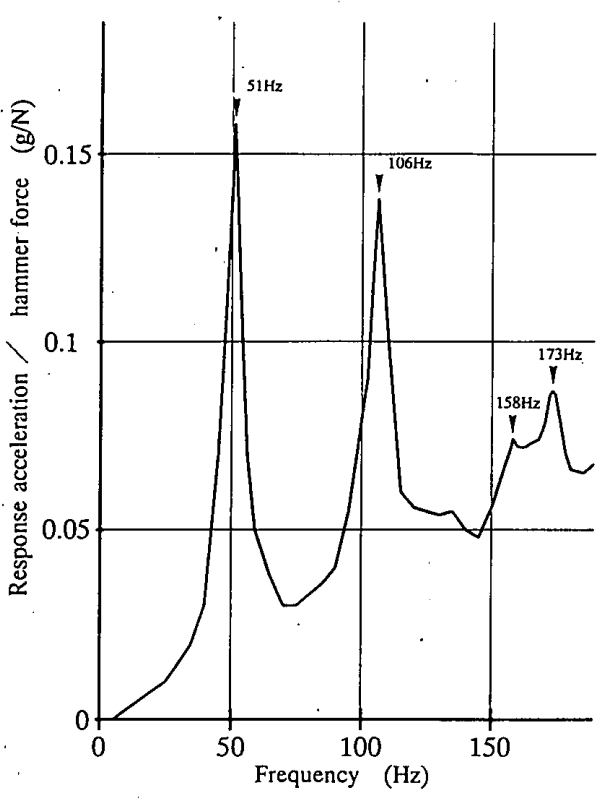

Fig.10 Frequency response function obtained by impact-hammer test for model diaphragm

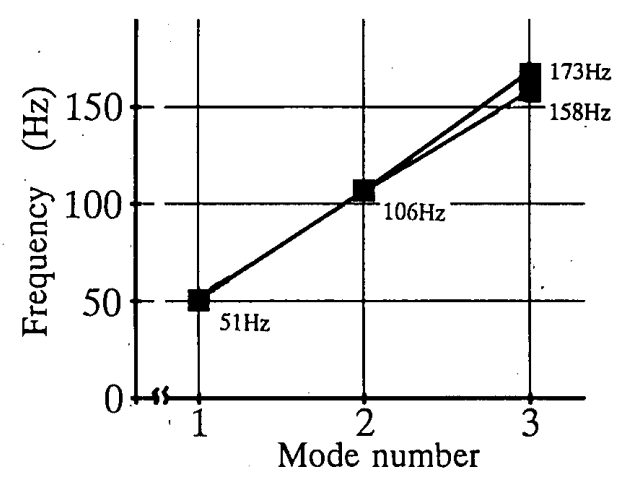

Fig.11 Relation between frequency and mode number for model diaphragm

求めた 1 次固有振動数に対応する減衰定数は，䄪 $2 \% て ~$ あった。

\section{2 模型ダイアフラムについての検討 \\ (1) 固有振動数}

Fig.10には，インパクトハンマー試験により得られた 各 node(node1 node9) に対応する周波数応答関数の和 が示してあるか，同図より，固有振動数の值は， 1 次が $51 \mathrm{~Hz} ， 2$ 次が $106 \mathrm{~Hz} ， 3$ 次が $158 \mathrm{~Hz}$ または $173 \mathrm{~Hz}$ であ ることがわかる。

Fig.11には，固有振動数とモード次数の関係が示して あるか，同図より，実大ダイアフラムと同样，固有振動 数とモード次数の間には 1 次比例の関係が存在している ことがわかる。このことは，模型ダイアフラムの面内振 動もせん断振動であることを窥わせると同時に，模型ダ イアフララムの性状が，実大ダイアフラムと同じ性状を持 つことを示唆するものでもある。
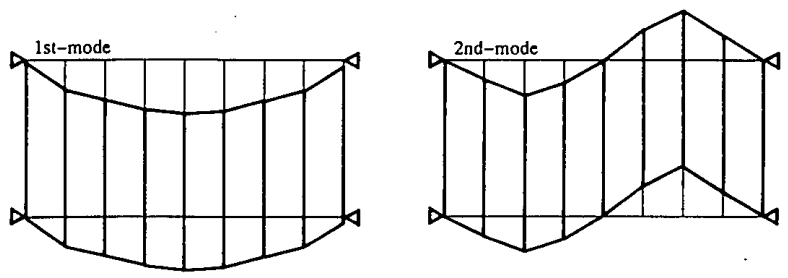

f $\mathrm{l}=51 \mathrm{~Hz}$

f $2=106 \mathrm{~Hz}$

Fig.12 Mode shapes obtained by impact-hammer test for model diaphragm

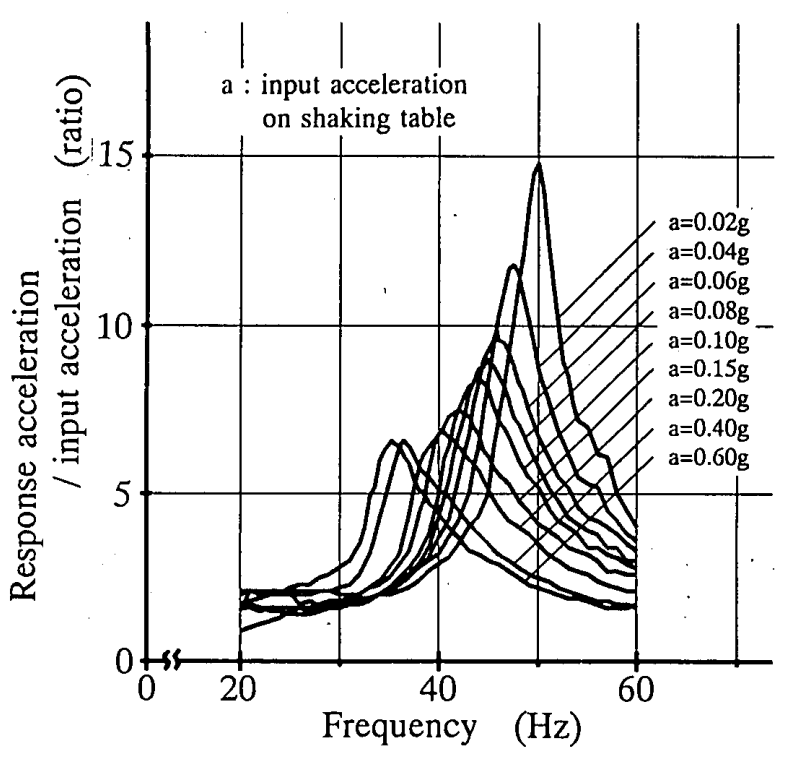

Fig.13 Variation of frequency response curves on mid-span accelaration obtained by shaking-table test for model diaphragm

(2) モード形

Fig.12には，Fig.10の周波数応答関数に基ついて，多 点参照モード解析により得られた 1 次及び 2 次の固有振 動モードが示してある。同図より，モード形は，実大夕゙ イアフラムの場合と同様, sine 曲線に近い形を示して いることがわかる。

(3) 入力加速度と 1 次固有振動数の関係

Fig.13には，振動台を用いた周波数応答実験において， 振動台の入力加速度を $0.02 \mathrm{~g} \sim 0.6 \mathrm{~g}$ の範囲で変化させた 場合の， 1 次固有振動数に対応するスパン中央部 （node5）の加速度応答曲線が示してある。同図より, 振動台の入力加速度の增加に伴い，固有振動数の值が低 下すると同時に応答倍率も低下する傾向が看取される。 その場合の固有振動数の低下の程度は, 振動台の入力加 速度が $0.02 \mathrm{~g}$ 時 $50 \mathrm{~Hz}, \quad 0.6 \mathrm{~g}$ 時 $35.5 \mathrm{~Hz}$ で，約 $30 \%$ の変化 が見られる。これは，ダイアフラムの変形性状が非線形 性を有するため，入力加速度の增加に伴い剛性が低下す ると同時に，減衰が大きくなることに起因すると考えら れる。

(4) 入力加速度と減衰定数の関係

Fig.14には，Fig.13の周波数応答曲線に基づき， 


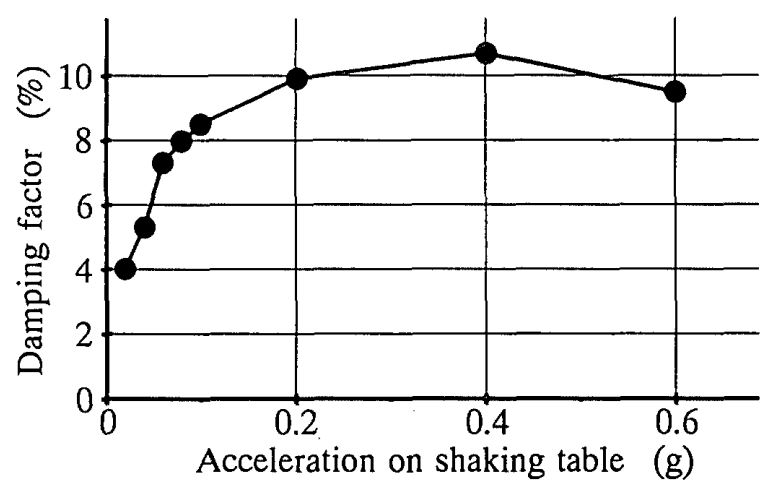

Fig.14 Relation between damping factor and accelaration on shaking-table for model diaphragm

$1 / \sqrt{2}$ 法により求めた減衰定数と入力加速度の関係が示 してある。同図より，入力加速度が $0.02 \mathrm{~g} \sim 0.1 \mathrm{~g}$ の範囲 においては入力加速度の增加に伴い減衰定数の値は増加 するが， $0.1 \mathrm{~g}$ を超えると減衰定数は $10 \%$ 前後の、ほぼ 一定の值を示していることがわかる。

また，インパクトハンマー試験において，Fig.10の周 波数応答関数に対するカーブフィティングにより得られ た， 1 次固有振動数に対応する減衰定数の值は $4.2 \%$ で あったか、この値は振動台実験の低入力時 $(0.02 \mathrm{~g}$ 時 4.0\%)の值と合致している。

\section{3 静的性状と動的性状の比較}

(1) 静的性状

Fig.15には，模型ダイアフラムに対して行った静的加 力試験のうち、スパン中央集中加力試験の荷重〜変位履 歴曲線が例示してある。

Table 2 には，実大及び模型ダイアフラムに対して行 った，静的正負繰り返し加力試験の結果が一括表示して ある。同表中 (a) の荷重値は加力荷重の合計（総荷重）， 同表中 (b) の変位は正負繰返し加力におけるスパン中央 部変位の絶対值の平均である。同表中 (c)の等価せん断 剛性 $(\mathrm{GA} / \kappa)$ とは，スパン中央部の変形が全てせん 断変形によるものと仮定して梁理論により計算したせん 断剛性の值である [式については〈付録 2$\rangle$ 参照]。同 表中 (d) の等価粘性減哀定数 ( $h \circ q)$ とは, 静的正負絽 り返し加力試験により得られた荷重〜スパン中央部変位 の履歴曲線に基づき、Jacobsen の方法" によって計算さ れた等価粘性減衰定数の值である。

なお，前述したように実大ダイアフラムの場合には振 動実験の变形は微小であったので，静的試験結果は初期 の繰り返し荷重時の結果のみが示してある。

(2) せん断振動の基本式に基つく固有振動数の推定

ダイアフラムの面内振動性状が，連続体のせん断振動 に類似していることについては前述したが、ここでは， ダイアフラムの静的せん断剛性を用い，連続体のせん断 振動理論に基ついて，固有振動数を推定する方法の適否

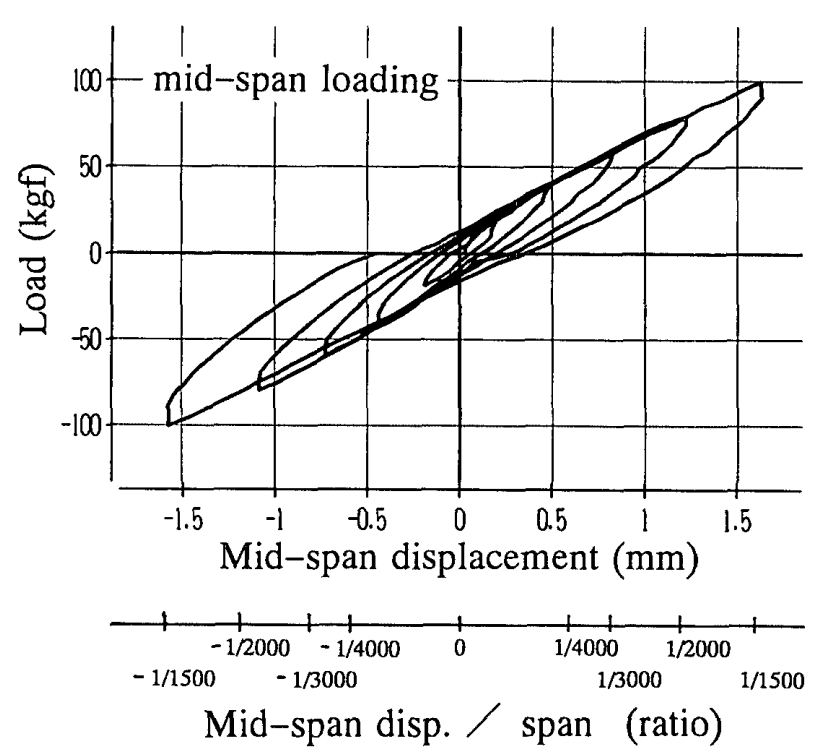

Fig.15 Hysteretic loops due to mid-span loading test for model diaphragm

Table 2 Results of static tests

\begin{tabular}{|c|c|c|c|c|}
\hline & \begin{tabular}{|c|} 
(a) \\
Total \\
lateral \\
load \\
(kgf)
\end{tabular} & $\begin{array}{c}\text { (b) } \\
\text { Disp. of } \\
\text { mid-span } \\
(\mathrm{cm})\end{array}$ & $\begin{array}{c}\text { (c) } * 1 \\
\text { Eq. shear } \\
\text { stiffness } \\
\text { GA/x }(\mathrm{kgf})\end{array}$ & \begin{tabular}{|c} 
(d) \\
Eq. viscous \\
damping \\
factor \\
h.. (\%)
\end{tabular} \\
\hline Full-scale & 1,200 & 0.030 & 764,000 & 2.0 \\
\hline \multirow{5}{*}{$\begin{array}{l}\text { Model } \\
\text { distributed } \\
\text { loading }\end{array}$} & 20 & 0.010 & 77,000 & 10.3 \\
\hline & 40 & 0.020 & 67,000 & 13.3 \\
\hline & 60 & 0.032 & 58,000 & 12.6 \\
\hline & 80 & 0.044 & 55,000 & 13.3 \\
\hline & 100 & 0.062 & 48.000 & 13.0 \\
\hline \multirow{5}{*}{$\begin{array}{l}\text { Model } \\
\text { mid-span } \\
\text { loading }\end{array}$} & 20 & 0.020 & 62,000 & - \\
\hline & 40 & 0.046 & 52,000 & 9.8 \\
\hline & 60 & 0.078 & 46,000 & 9.8 \\
\hline & 80 & 0.116 & 42,000 & 9.6 \\
\hline & 100 & 0.160 & 37,000 & 10.0 \\
\hline
\end{tabular}

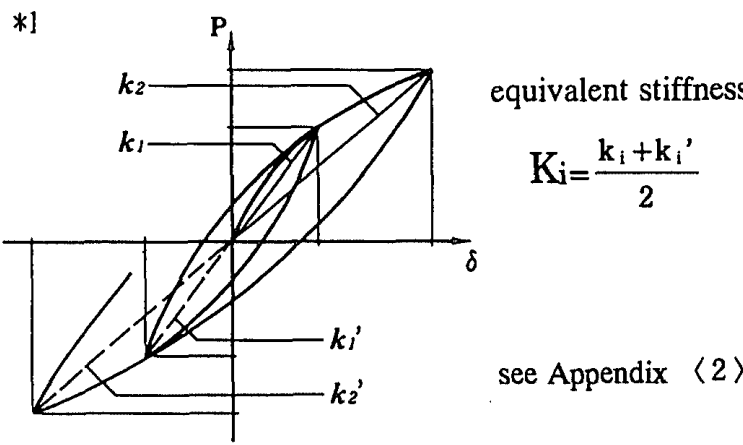

について検討する。

Fig.16には；実大及び模型ダイアフラムについて，質 量, スパン及びせん断剛性 [ Table 2 (c) 欄中の最大の 数値：実大の場合 764,000kgf, 模型の場合 77,000kgf ] を用い，連続体のせん断振動理論 [〈付録 1〉(付 1 ) 


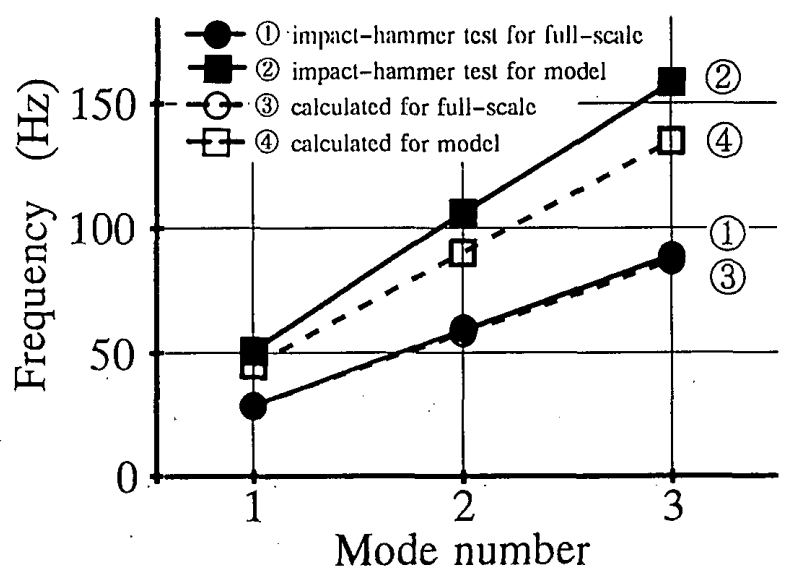

Fig.16 Comparison between experimental and calculated natural frequencies for full-scale and model diaphragms

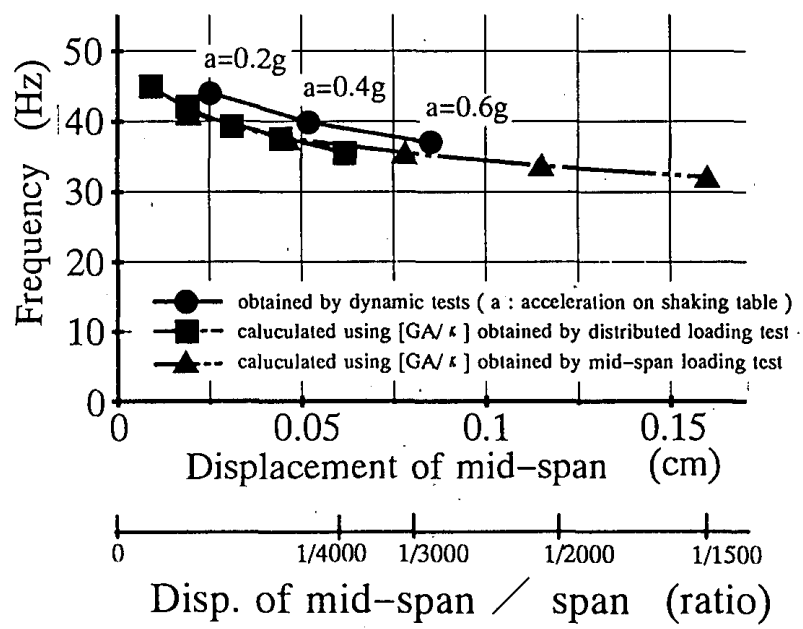

Fig.17 Comparison of first natural frequency between experiment and calculation for model diaphragm

式参照] に基づいて求めた 1 次 3 次の固有振動数とモ 一ド次数の関係が示してある（同図中(3)と(4)）。また， 同図中には，前述したインパクトハンマー加振実験によ り得られた固有振動数の值 [ 3.1(1) 及び 3.2(1) 参照] す 示してある (同図中(1)と(2))。同図より，1～3 次の固 有振動数について, 実大ダイアフラムの場合には実験值 之計算値はほぼ一致し（11)と(3)比較），模型ダイアフ ラムの場合には計算値が約 15\% 実験值を下回ることが わかる（2)と(4)を比較）。

次に，模型ダイアフラムについて 1 次固有振動数とス パン中央部の変形量との関係について検討する。

Fig.17には，振動台を用いた周波数応答実験における 振動台の各入力加速度 $(0.2 \mathrm{~g}, 0.4 \mathrm{~g}, 0.6 \mathrm{~g})$ に対応する 1 次固 有振動数とスパン中央部 (node5) の共振時最大応答変位 との関係が示してある。また，同図中には，静的試験に より得られた各荷重時の等価せん断㓮性 [ Table 2 (c) の值]に基つきき計算した 1 次固有振動数と各荷重時のス パン中央部変位との関係が示してある。同図より，共振
時のスパン中央部変位に対応する 1 次固有振動数につい $て$, 静的加力実験より得られた等価せん断剛性に基つい た計算值は実験値を䄪 $10 \%$ 下回っているものの，両者 の傾向は良く一致していることがわかる。このことは, ダイアフラムの固有振動数を, 静的試験の等価面内せん 断剛性 (GA/ $\kappa)$ を用いて，せん断振動理論に基づいて 推測することが可能であることを示唆している。

(3) 減衰定数

実大ダイアフラムについては，静的試験で得られた微 小変形時（スパンに対する変形の比は約 $1 / 40,000$ ）の等 価枮性減衰定数の值は䄪 $2 \%$ で,これは，3.1(4)で述 てた動的試験の結果と一致している。同様に，模型の場 合には，スパン中央部の変形量が $2.5 \times 10^{-3} \mathrm{~cm}$ （スパ ンに対する変形の比は約 1/10,000）以上においては, 静 的及び動的試験結果 [ Table 2 (d) と Fig.14 参照] とも に減衰定数は $10 \%$ 前後の値を示し, 両者の值は良く一 致していることがわかる。

\section{§4. まとめ}

木質ダイアフラムの振動特性を明らかにするために, 辺長比約 $1 / 2$ の実大及び模型ダイアフラムを対象とし て行った動的試験及び静的試験より，明らかになったこ とをまとめれば次のようになろう。

(1)ダイアフラムの面内振動における固有振動数とモー ド次数の関係は，1 次比例の関係にあり，連続体のせん 断振動理論に合致する。

(2) ダイアフラムの質量、スパン及び静的等洒せん断剛 性を用いて，連続体のせん断振動理論により計算される 固有振動数の值は，動的実験で得られたダイアフラムの 固有振動数と一致する傾向にあり，静的等価せん断剛性 に基づき固有振動数を推定する方法は有効である。

(3) 静的試験による等価粘性滅衰定数と動的試験におい て得られた減衰定数は一致する傾向にある。

\section{【謝辞】}

実験に供した実大ダイアフラムは、トシワ技建株式会 社並びに株式会社新井建築工学研究所の作製・設計にな るもので，実験実施に際しては森林総合研究所木材利用 部構造性能研究室杉本健一研究員に多大なる御尽力を戴 きました。

実大実験実施に当たっては，職業能力開発大学校建築 構造研究室及び明治大学理工学部建築学科構造第 3 研究 室の学生諸氏，また，模型実験実施に当たっては職業能 力開発大学校建築構造研究室に在籍した小幡勝彦君を始 めとする学生諸氏に，多大なる御協力を戴きました。

ここに記して，各位の御協力に対し深甚なる感謝の意 を表します。 
付録 (Appendixes)

〈付録 1〉連続体の振動理論

一般に，連続体の振動理論によればたをえ(16)，両端をピン 支持された連続体の固有振動数は，せん断振動の場合には ( 付 1) 式，曲け振動の場合には (付 2) 式でそれぞれ与えられ る。

せん断振動の場合の固有振動数

$$
\left.\mathrm{f}_{\mathrm{n}}=\frac{\mathrm{n}}{2} \sqrt{\frac{\mathrm{GA} / \kappa}{(\mathrm{W} / \mathrm{g}) \cdot 1}} \cdots \cdots \cdots \cdot \ldots \text { (付 } 1\right) \text { 式 }
$$

\section{曲げ振動の場合の固有振動数}

$$
\left.f_{n}=\frac{n^{2} \pi}{2} \sqrt{\frac{E I}{(W / g) \cdot 1^{3}}} \cdots \cdots . . . \text { (付 } 2\right) \text { 式 }
$$

ここに,

$$
\begin{aligned}
& \text { f } \mathrm{n} \text { : } \mathrm{n} \text { 次の固有振動数 } \\
& \text { n : } \text { : } \\
& \mathrm{GA} / \kappa \text { : せん断㓮性 } \\
& \left\{\begin{array}{l}
\mathrm{G}: \text { せん断弾性係数 } \\
\mathrm{A}: \text { 断面積 } \\
\kappa: \text { 形状係数 }
\end{array}\right. \\
& \text { E I : 曲け佣性 } \\
& \left(\begin{array}{l}
\mathrm{E}: \text { : ヤング係数 } \\
\mathrm{I}: \text { 断面 } 2 \text { 次モーメント }
\end{array}\right. \\
& \text { W ： 試験体総重量 } \\
& \text { g : 重力加速度 } \\
& 1 \text { ： 試験体スパン }
\end{aligned}
$$

〈付録 2〉各荷重条件に対する梁のせん断変形

梁の変形が全てせん断変形によるものと仮定した場合の， 梁中央部の樷位と実験により求められるせん断剛性 (GA/ $\kappa)$ は次のようになる。

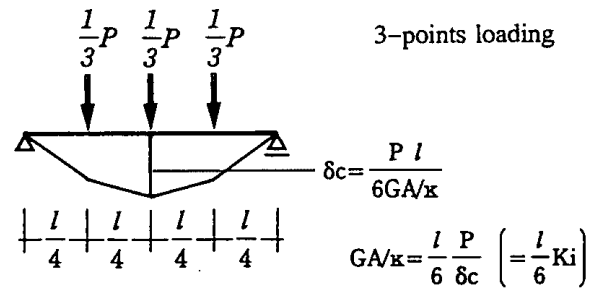

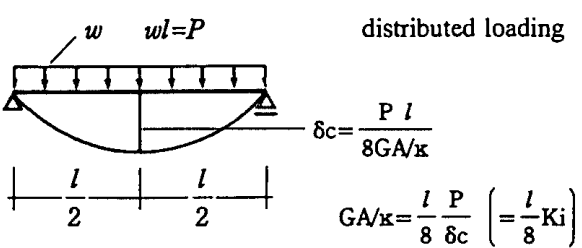

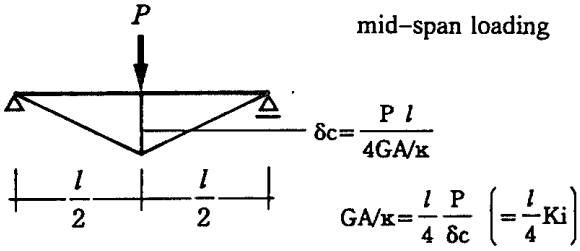

\section{参考文献 (References)}

1) J.M.Carney, "Bibliography on Wood and Plywood Diaphragms" Journal of Structural Division, ASCE, Vol.101, No.ST11, pp.2423-2436, Nov. 1975

2) 鈴木 秀三, 野口 弘行, 神谷 文夫 他: 木質ダイアフラ 厶に関する研究 (1) (9), 日本建築学会大会学術講演梗 概集（北陸）C 構造 II，pp.97～114，1992年 9月

3) 鈴木 秀三，野口 弘行，木上 浩: 木質系多アフラムに 関する研究 (10), 日本建築学会大会学術講演梗概集（関東） C 構造 II，pp.987 989, 1993 年 9 月

4) 藤野 栄一，鉿木 秀三 : 木質ダイアフラムの動的性状に関 する模型実験，日本建築学会大会学術講演梗概集（関東） C 權造 II, pp.985 986，1993 年 9 月

5) 藤野 栄一，鉿木 秀三 : 木質ダイアフラムの動的性状に関 する模型実験（その 2 ），日本建築学会大会学術請演梗概 集 (関東) C 榑造 II, pp.97 98，1994 年 9 月

6) 志賀 敏男 : 搆造物の振動，共立出版，1976

7) 日本建築学会 : 建築物の耐震設計資料, 丸善(㑣)，1981

（1994年 6 月10日原稿受理，1994年11月14日採用決定） 